\title{
Developing the Format and Samples of Teaching Materials for Scientific Creativity in the Ordinary Science Curriculum -Including Teachers' Practice and Reflection-
}

\author{
Jongwon Park* \\ Chonnam National University
}

\begin{abstract}
Scientific creativity is necessary for all ordinary students in ordinary school settings. In this study, a practical format for teaching scientific creativity is suggested, and sample teaching materials based on this format are developed. To facilitate the practical use of the teaching materials in ordinary schools, the model of IS $\mathrm{CA}$ (Iterative Small Scale Scientific Creative Activity) was proposed. Using this format and the proposed teaching materials, a brief in-service program was developed and implemented. Here, the aim is to improve teachers' actual professional ability to develop their own teaching materials rather than just using the pre-developed teaching materials provided by the researcher. Positive responses about the in-service program were collected from the teachers, and the results also showed that the development of teaching materials by teachers was possible. Therefore, I expect that the teaching of scientific creativity by ordinary teachers is possible for ordinary students in ordinary school contexts. Finally, based on the results and experiences of this study, a curriculum for teaching scientific creativity is suggested.
\end{abstract}

Key words: scientific creativity, teacher's professionalism, in-service program, curriculum for scientific creativity, teaching materials.

\section{Introduction}

Teaching creativity has been emphasized mainly in the areas of gifted education and special education. However, recently, the ordinary curriculum has started to stress the importance of teaching creativity to ordinary school students. For example, 'Science for All Americans' noted that 'The science classroom ought to be a place where creativity and invention $\cdots$ are recognized and encouraged." (AAAS, 1990, p. 204). Also, the Australian Curriculum, Assessment and Reporting Authority (ACARA) mentioned, in their science curriculum, that "Skills and understanding related to numeracy, literacy and ICT need to be further developed and used in all learning areas, as do thinking skills and creativity." (National Curriculum Board, 2009, p. 12). In Korea also, according to the recently revised curriculum, it has been announced that "(the revised) curriculum is a student-centered curriculum for improving learner's autonomy and creativity" (MEST, 2009, p. V). According to this basic direction, the science curriculum is organized into subject areas and creative experiential activities. Since many researchers have stressed the domain specificity of creativity (Baer, 1999; Conti, Coon, \& Amabile, 1996; Kim, 2005; Mansfield \& Busse, 1981; Plucker, 2004; Weisberg, 2006; Wolpert, 1992), scientific creativity rather than general creativity has been the concern of science educators. Therefore, Hu \& Adey (2002) developed an assessment tool for scientific creativity, based on their model of scientific creativity consisting of products, traits, and processes. Park (2004) also suggested a three dimensional model of scientific creativity having three components: creative thinking, scientific knowledge, and scientific inquiry skills.

Besides theoretical research on creativity, practical approaches such as developing and applying teaching programs for creativity have

*Corresponding author: Jongwon Park (jwpark94@jnu.ac.kr)

**Received on 1 February 2012, Accepted on 15 March 2012

***This work was supported by the Korea Research Foundation Grant funded by the Korean Government (KRF-2009-327-B00643). 
also been conducted. For example, Treffinger et al. (1993) reported that about over 250 programs for nourishing creativity had been developed until 1993, and Scott et al. (2004a, 2004b) categorized 11 types of training program (e.g., training for producing ideas through interaction, training for imagination, $\cdots)$, 8 types of activity (e.g., finding problems, choosing concepts, $\cdots$ ), and 17 types of creative thinking (e.g., divergent thinking, metacogniton, analogy, $\cdots$ ), based on the analysis of 156 programs for creativity. In the area of scientific creativity, Park et al. (2008) developed about 30 activities in the three main categories: creative thinking in scientific creativity, conducting scientific inquiry creatively, and understanding/applying scientific knowledge creatively. Park et al. (2010) also developed on-line programs to help more students to experience scientifically creative activities through the internet.

In addition, many studies investigating the effectiveness of the developed programs have been performed. For instance, Rose \& Lin (1984), based on meta-analysis, reported that the average effect size of creativity programs was about 0.47, and Scott et al. (2004a) noted that the overall effect size of 70 programs for creativity was about 0.68. Park and Jee (2010) also obtained evidence about the effectiveness of guidelines for thinking creatively in scientific contexts.

Even though there have been many studies involving theoretical and practical approaches to improving scientific creativity, those efforts have not been extended to ordinary science education for ordinary students in ordinary school contexts.

One of the reasons for this may be because the teaching of scientific creativity is not familiar or accessible to ordinary science teachers. For instance, Cropley (1992) offered the criticism that nearly $95 \%$ of teachers regarded traditional techniques such as memorization, accuracy, or recognition of learned materials as important aspects in learning science (p. 20). Yager (1989) also mentioned that convergent thinking, rather than divergent thinking or more creative processes, was emphasized in the school science curriculum and in teaching and assessing science.

The above criticisms do not mean that there were not effective and sufficient teaching methods, strategies, and concrete teaching materials. Rather, they indicate that there may be a lack of linkage between theory and practices. Regarding this, Corte (2000) noted as follows:

"Recent research on learning and instruction
has substantially advanced our
understanding of the processes of
knowledge and skill acquisition. However,
school practices have not been innovated
and improved in ways that reflect this
progress in the development of a theory of
learning from instruction." (Corte, 2000)

To overcome this gap between theory and practice, we need to take a special approach. That is, the important point is the improvement of teachers' profession in developing and applying the teaching programs by themselves, instead of the provision of pre-developed teaching materials by researchers and the convey of the methods and the procedures for how to apply the developed materials to teachers. Therefore, the basic concern of this study is the possibility that science teachers can develop teaching materials by themselves for the purpose of using them in their school teaching. Then, it is expected that science teachers could adapt, rather than adopt, teaching materials according to different teaching circumstances, including the teacher's specific teaching goal, the students' interest and levels of ability, and the different contents of the knowledge that must be imparted.

Of course, in order to achieve this, besides the in-service training course for the purpose of improving teachers' profession, teachers' 
autonomous and enthusiastic involvement in developing and applying teaching materials for teaching scientific creativity is necessary. Teachers need to be involved in small but spontaneous teachers' study groups supported by the district offices of education. Through the inservice training of this study, we will give basic information to teachers about teaching scientific creativity and guidance about how to develop teaching materials by themselves. Therefore, in this study, we first developed the basic format of teaching materials for nourishing scientific creativity, along with some sample materials, and then tried to improve teachers' abilities to develop their own teaching materials.

Another goal of this study is to suggest a curriculum for scientific creativity in order to generalize the experience of this study to a wider range of situations for ordinary science teaching. With this background, the detailed research purposes of this study are:

(1) To suggest a practical format and samples of teaching materials for scientific creativity in ordinary school contexts under the ordinary science curriculum.

(2) To develop and implement a brief inservice program for elementary school teachers to help the development of their own teaching materials for use in their schools

(3) To analyze teachers' responses to the inservice program and their experiences of developing their own teaching materials and to analyze features of the teaching materials developed by teachers.

(4) To suggest a curriculum for scientific creativity.

\section{Background}

For teaching scientific creativity, Park (2004) proposed a model of scientific creativity focused on cognitive aspects, which is shown in Figure 1. According to this model, for scientific creativity, in contrast to ordinary or content-free creativity, creative thinking should be activated during the process of conducting scientific inquiry or the process of understanding/applying scientific knowledge.

Regarding this model, someone may insist that convergent thinking is not creative thinking but logical thinking, because it leads to closed answers rather than open-ended solutions. Of course, convergent thinking by itself cannot be regarded as a type of creative thinking. However, because our main concern is scientific creativity, the creative thinking should be valuable in science, be useful for specific scientific problem solving, or lead to the

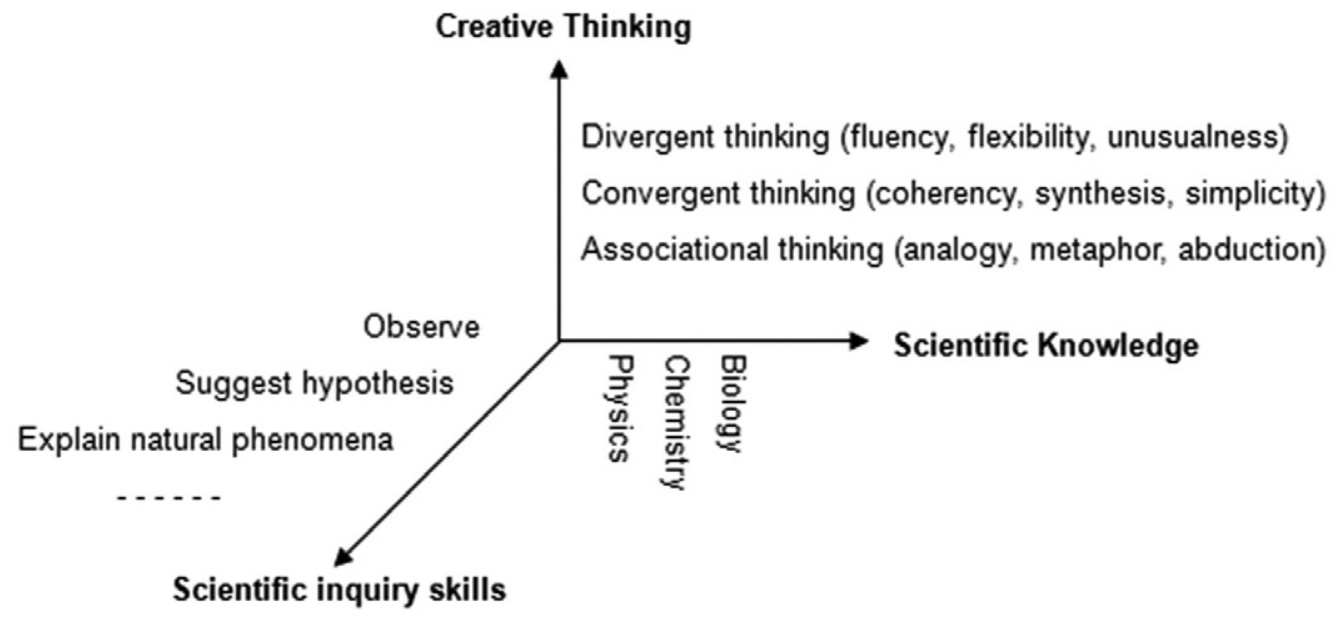

Fig. 1 Model of Scientific Creativity (MSC) 
advancement of science. To achieve this, convergent thinking should be combined with other types of creative thinking. That is, for scientific creativity, after suggesting many various, unusual, and original ideas at the initial stage, the suggested ideas should be checked, refined, articulated, or selected based on scientific knowledge and inquiry processes using convergent thinking.

In this model, nine elements are involved; fluency, flexibility, unusual thinking, coherence, synthesis, simplicity, associational thinking, elaboration, and originality. The operational definition of each element for teaching and assessing scientific creativity in schools can be seen in Park' s study (Park, 2011).

Based on the model of scientific creativity, various types of scientific creativity activities have been developed (Park, et al., 2008; Park, et al., 2009; Park et al., 2010, Park, unpublished).
In Figure 2, some types of scientific creativity activities are described.

For teaching scientific creativity, the $\mathrm{AGA}^{2}$ teaching model (Figure 3) was applied to develop concrete teaching and learning materials (Park, et al., 2008).

In the first step (spontaneous activity) given in Figure 3, students are provided with the task to be solved. At that stage, there are no guidelines or hints about how to think creatively. Therefore, while some students may show a high level of creativity in solving the task, many others solve the task by using common sense or in conventional ways, and also, some students may experience difficulties in solving the task.

Therefore, in the second step, we provide actual guides about how to think creatively to solve the task. Of course, these guides are not general rules for all types of scientific creativity but may differ according to the tasks. However,

\begin{tabular}{|c|c|}
\hline Type & Sub-Type \\
\hline $\begin{array}{c}\text { I. } \\
\text { Thinking } \\
\text { creatively in } \\
\text { scientific context }\end{array}$ & $\begin{array}{l}\text { I-1. Inventing various alternative scientific usages } \\
\text { I-2. Making prediction scientifically in unusual situations } \\
\text { I-3. Playing the game of if .. then...' in scientific contexts } \\
\text {... } \\
\text { I-6. Drawing a scientific concept map/mind map creatively } \\
\ldots \\
\text { I-8. Combining things to invent something new } \\
\text { I-9. Making a story using scientific figures, data, or situations } \\
\ldots \\
\text { I-12. Suggesting a scientific analogy creatively } \\
\text { I-13. Representing scientific phenomena in the form of a proverb } \\
\text {... }\end{array}$ \\
\hline $\begin{array}{c}\text { II. } \\
\text { Conducting } \\
\text { scientific inquiry } \\
\text { creatively }\end{array}$ & $\begin{array}{l}\text { II-1. Making scientific observations creatively } \\
\text { II-2. Finding new observations by changing conditions } \\
\ldots \\
\text { II-5. Suggesting scientific inquiry problems } \\
\text { II-6. Suggesting scientific hypotheses creatively } \\
\text { II-7. Designing or improving scientific experiments creatively } \\
\ldots\end{array}$ \\
\hline $\begin{array}{c}\text { III. } \\
\text { Understanding } \\
\text { and applying } \\
\text { scientific concepts } \\
\text { creatively }\end{array}$ & $\begin{array}{l}\text { III-1. Visualizing a scientific explanation } \\
\ldots \\
\text { III-4. Naming or suggesting signs for new scientific ideas or products } \\
\text { III-5. Changing the conventional definitions of scientific concepts } \\
\ldots \\
\text { III-8. Solving science problems in various ways } \\
\ldots \\
\text { III-11. Applying experimental results to new situations } \\
\ldots\end{array}$ \\
\hline
\end{tabular}

Fig. 2 Examples of scientific creativity activities 


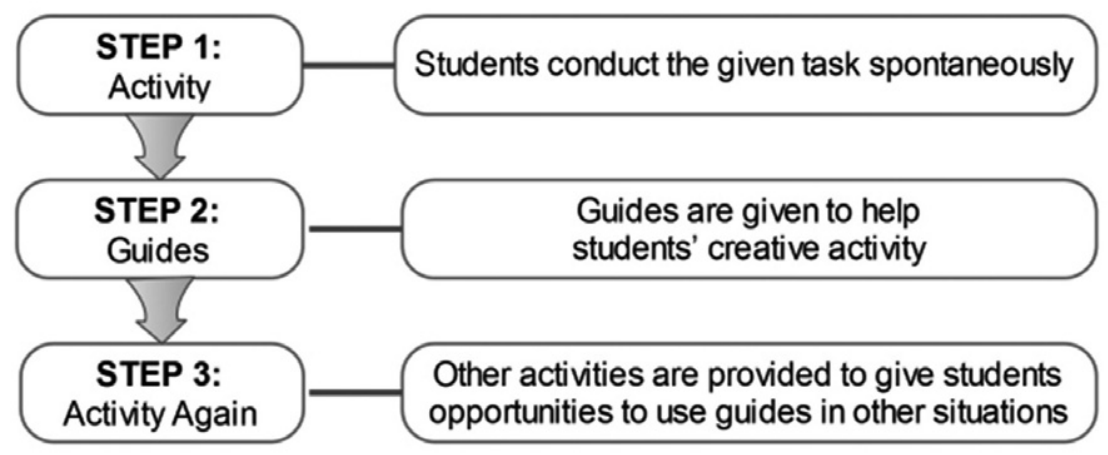

Fig. $3 A G A^{2}$ model for scientific creativity activity

because the basic ideas of the guides are closely related to the three types of creativity thinking in the MSC (Model of Scientific Creativity as shown in Figure 1), the guides can be easily modified according to the content or characteristics of the task. In Park \& Jee's (2010) study, you can find the actual effects of the guides provided in the second step of scientific creativity.

The final step is to apply the guides used in the second step to other new situations.

In fact, these activities were initially developed for students who are gifted in the area of science. However, scientific creativity is necessary not only for gifted students but for all science students. Therefore, we need to revise these activities into other forms that are appropriate for ordinary science students in usual school contexts under the ordinary science curriculum. Also, when students complete the above activities (as shown in Figure 2) based on the $\mathrm{AGA}^{2}$ model, it usually took about 2 or 3 hours, and sometimes more than 3 hours. This is because the suggestion of new ideas is usually not trivial. In this case, the above original form of the materials (as shown in Figure 2) and the $\mathrm{AGA}^{2}$ model cannot be used in ordinary classroom teaching in its original form. Therefore, in this study, we explored and proposed an alternative way of teaching scientific creativity for ordinary school students.

\section{Procedure}

\section{Overall process}

In this study, we first developed a practical format for teaching materials that could be used to teach scientific creativity with the purpose of using this format in ordinary school contexts. At first, we limited the 'contexts' for teaching scientific creativity to the following four contexts; teaching scientific creativity in the classroom, in the laboratory, and in special classes such as science inquiry classes, and testing scientific creativity through performance assessment. And we developed two sample teaching materials for each teaching context (as a result, eight sample materials were developed in total). Characteristics and details about the format and samples of teaching materials will be described in the results section.

To test the plausibility and practicality of the suggested format and sample teaching materials, elementary school teachers participated in a short in-service program designed to introduce the main characteristics of scientific creativity and the format, and to explain how to use the sample materials. During about one month following the in-service program, they were asked to develop their own teaching materials for the purpose of using them in their schools. Then we identified teachers' difficulties in developing teaching materials, and analyzed the 
features of the teaching materials developed by teachers. Finally, based on an analysis of the teachers' responses and their developed teaching materials, we suggested a curriculum for teaching scientific creativity to ordinary science students. The overall process of this study is shown in Figure 4.

\section{In-service program for elementary school teacher}

Using the format of teaching materials with sample activities, we first developed a short inservice program to help elementary school teachers to understand the basic nature of scientific creativity, a model of scientific creativity (Figure 1), various types of teaching materials (Figure 2), a method of application of the teaching materials based on the $\mathrm{AGA}^{2}$ model
(Figure 3), and an operational definition of elements of creative thinking. Then, based on the general understanding of scientific creativity, we introduced the format of the teaching materials and sample activities for teaching creativity in ordinary schools. The basic contents of the in-service program are described in Table 1.

The duration of the in-service program was relatively short, that is, just 3 hours. Of course, the more time is assigned to the in-service program, the more effective the program will be. However, the teachers that participated in this study were members of a teachers' study group supported by the district office of education. Therefore, it was assumed that the teachers were autonomous and enthusiastic about teaching scientific creativity. They were able to

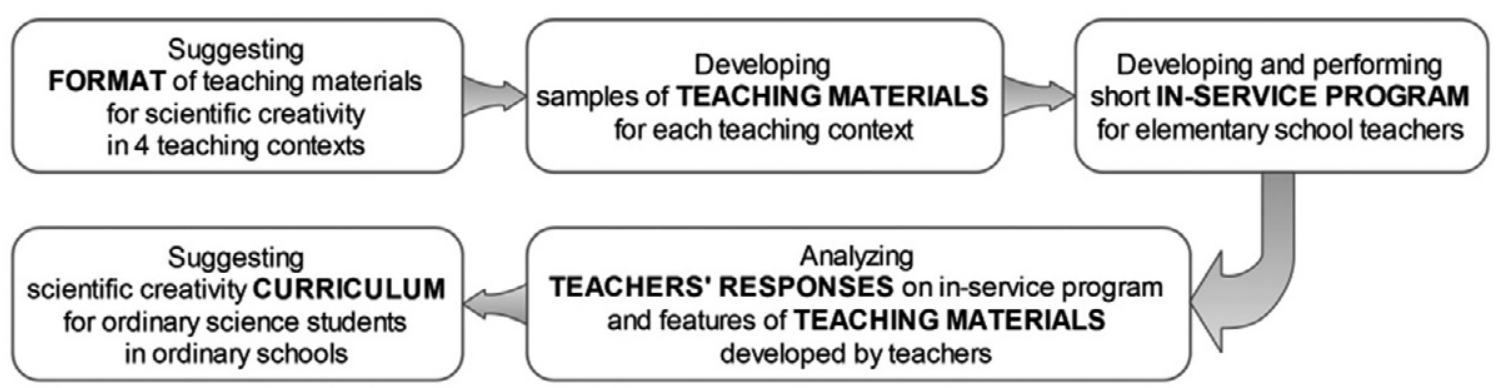

Fig. 4 Overall process of this study

\section{Table 1}

Basic contents of in-service program

Category

Contents

Basic characteristics of scientific creativity and model of scientific creativity
- Basic nature of scientific creativity including domain-specificity, the relationship between fluency and originality, and so on

- Basic characteristics of the model of scientific creativity (Figure 1)
Operational definition of creative thinking elements

Scientific creativity activities and $\mathrm{AGA}^{2}$ model

Format of teaching materials and sample activities in four teaching contexts
- Operational definitions of nine elements of creative thinking

- Various types of activities (Figure 2)

- $\mathrm{AGA}^{2}$ model (Figure 3), especially, the importance of the 'Guide'

- Teaching format of teaching materials developed in this study

- Eight sample activities developed in this study (2 activities for each

'Teaching Context')

- Discussion about how teachers can utilize the sample activities to 60 
confront any unpredicted difficulties in following the in-service program and in developing their own teaching materials after the in-service program. We checked whether the in-service program was actually helpful to participants and identified their difficulties. These difficulties were used to make recommendations for a more effective in-service training course in the future. We also analyzed the features of the teaching materials developed by the teachers after a few weeks.

\section{Participants}

In this study, seven elementary school teachers participated. According to Table 2, it was found that all of the participants except for one person had some experiences related to teaching creativity. After finishing 3 hours of in-service program, they developed their own activities with the purpose of using them in their schools in ordinary conditions. They submitted the developed teaching materials to me, and gave responses to me about the in-service program and the experience of developing teaching materials.

\section{Questionnaire}

We obtained responses about the in-service program using the questionnaire shown in Table 3. Questions (number I-1 I-3) asking for basic information about the participants, such as their number of years of teaching as a teacher, their experience of teaching scientific creativity and so on, are omitted in Table 3.

The teaching materials shown in Figure 2 and the $\mathrm{AGA}^{2}$ model in Figure 3 cannot be applied to teaching creativity in ordinary schools in their current form. Therefore, instead of this, we asked about the new format of the teaching materials (question $\mathrm{V}-1, \mathrm{~V}-2$ ) and the sample activities developed for teaching creativity in ordinary schools (question V-3, V-4).

\section{Other data}

Besides analyzing teachers' responses using the questionnaire (Table 3), we also interviewed them informally during the in-service program to obtain more information. We interviewed the teachers again after they developed their teaching materials in order to obtain information about their development experiences as well as the teachers' recognition of the principles of teaching scientific creativity in their schools.

\section{Limit of this study}

Even though the basic goal of this study is to

Table 2

Participants

\begin{tabular}{cll}
\hline \hline $\begin{array}{c}\text { Years of teaching } \\
\text { as teacher (years) }\end{array}$ & $\begin{array}{c}\text { Time participating in other } \\
\text { in-service programs about } \\
\text { creativity (hours) }\end{array}$ & \multicolumn{1}{c}{ Personal experience related to teaching creativity } \\
\hline 19.6 & 60 & Developing some teaching materials for creativity \\
\hline 14.3 & 36 & Teaching creativity using mind maps and brainstorming \\
\hline 15 & 20 & Teaching creativity in science class \\
\hline 10 & 0 & None \\
\hline 11 & 60 & Participating in a creativity camp \\
\hline 16 & 35 & Teaching creativity to teachers in an in-service program \\
\hline 120 & $\begin{array}{l}\text { Teaching creativity in the center for gifted education in } \\
\text { science }\end{array}$ \\
\hline
\end{tabular}




\section{Table 3}

Questions for obtaining teachers' responses

\begin{tabular}{|c|c|}
\hline Category & Questions \\
\hline \multirow{2}{*}{$\begin{array}{l}\text { Model of } \\
\text { scientific } \\
\text { creativity }\end{array}$} & II-1. Can you understand the model of scientific creativity well? \\
\hline & $\begin{array}{l}\text { II-2. Do you think that the model of scientific creativity is useful for teaching scientific } \\
\text { creativity? }\end{array}$ \\
\hline \multirow{3}{*}{$\begin{array}{l}\text { Elements of } \\
\text { scientific } \\
\text { creativity }\end{array}$} & III-1. Can you understand nine elements of scientific creativity well? \\
\hline & $\begin{array}{l}\text { III-2. Do you think that operational definitions of elements of scientific creativity are useful } \\
\text { for teaching scientific creativity? }\end{array}$ \\
\hline & $\begin{array}{l}\text { III-3. Are there any unnecessary elements in teaching scientific creativity in schools? Or are } \\
\text { there any additional elements which are necessary for teaching scientific creativity in } \\
\text { schools? }\end{array}$ \\
\hline \multirow{5}{*}{$\begin{array}{l}\text { Four contexts } \\
\text { for teaching } \\
\text { scientific } \\
\text { creativity }\end{array}$} & $\begin{array}{l}\text { IV-1. Can you understand the suggested four contexts for teaching scientific creativity in } \\
\text { schools well? }\end{array}$ \\
\hline & $\begin{array}{l}\text { IV-2. Do you think that the four contexts are useful in teaching scientific creativity in } \\
\text { schools? }\end{array}$ \\
\hline & $\begin{array}{l}\text { IV-3. Do you think that the four contexts are practical in teaching scientific creativity in } \\
\text { schools? }\end{array}$ \\
\hline & $\begin{array}{l}\text { IV-4. Do you think that some conditions or support are necessary for more effective } \\
\text { teaching scientific creativity in each context? }\end{array}$ \\
\hline & $\begin{array}{l}\text { II-5. Are there any other contexts for teaching scientific creativity in schools? If so, describe } \\
\text { them briefly. }\end{array}$ \\
\hline \multirow{4}{*}{$\begin{array}{c}\text { Format of } \\
\text { teaching } \\
\text { materials and } \\
\text { sample } \\
\text { activities }\end{array}$} & $\begin{array}{l}\text { V-1. In the suggested format of teaching materials, there are various items (e.g., types of } \\
\text { scientific creativity, elements of scientific creativity). Do you think that those all items are } \\
\text { necessary? }\end{array}$ \\
\hline & $\begin{array}{l}\text { V-2. Do you think that some additional items are necessary in the teaching materials? If so, } \\
\text { describe the additional items briefly. }\end{array}$ \\
\hline & $\begin{array}{l}\text { V-3. Do you think that more sample activities of teaching materials are necessary besides } \\
\text { the eight sample activities? }\end{array}$ \\
\hline & $\begin{array}{l}\text { V-4. Do you think that the sample activities of eight teaching materials should be given to } \\
\text { other teachers, if they want them? }\end{array}$ \\
\hline \multirow{3}{*}{$\begin{array}{l}\text { Development } \\
\text { of teaching } \\
\text { materials }\end{array}$} & $\begin{array}{l}\text { VI-1. You will develop your own teaching materials with the purpose of using them in your } \\
\text { school. How many materials can you develop? }\end{array}$ \\
\hline & $\begin{array}{l}\text { VI-2. Are sample activities of teaching materials helpful for developing your own teaching } \\
\text { materials? }\end{array}$ \\
\hline & VI-3. What kinds of support are necessary for developing your own teaching materials? \\
\hline
\end{tabular}

nourish teachers' professional ability so that they can develop teaching materials by themselves, the quality of the developed materials was not assessed. To test the effectiveness of the developed teaching materials, we need to apply the materials during actual classroom teaching. However, in this study, the teaching materials developed by the teachers were not applied in their schools due to the limits on the scope of this study. Instead, in this study, we explored the possibility of teachers' development of their own teaching materials, identified difficulties in improving teachers' developing abilities for future study, and investigated various features of the developed materials. 


\section{Results}

\section{Practical format of teaching materials for scientific creativity in ordinary schools}

In this study, we tried to find concrete teaching methods which can be used in the ordinary school system to teach scientific creativity. To do this, we determined that teaching scientific creativity is possible in the following four contexts: (1) classroom teaching, (2) laboratory teaching, (3) teaching science in special classes such as science classes, and (4) performance assessment of science. The reason that performance assessment is included is because usually a performance assessment task is given as an extended classroom activity or homework and contains a learning aspect.

The format of teaching materials for scientific creativity is shown in Figure 5 and an example of such teaching materials is given in the appendix. A more detailed explanation about Figure 5 is as follows.

\begin{tabular}{|l|}
\hline Title: \\
\hline Grade: \\
\hline Teaching Context: \\
\hline Type of scientific creativity activity: \\
\hline Elements of scientific creativity: \\
\hline Activity with textbook contents: \\
\hline Examples of activity results: \\
\hline Guide for creative thinking: \\
\hline Tip for use and transformation of activity: \\
\hline
\end{tabular}

Fig. 5 Basic format of teaching materials for scientific creativity

- Time: The creativity activity suggested in this study will be used under the given science curriculum. Therefore, a time of 10 or 15 minutes is appropriate for performing the creativity activity during the ordinary science learning process. Of course, many educators may insist that a longer time is necessary for inventing creative ideas. However, in this study, I assumed that even small activities can improve students' creative thinking if these small activities are performed repeatedly or iteratively over a long period from the lowest grade of elementary school to junior high school. That is, if even small activities are conducted iteratively over many years, it can be predicted that students' attitude and ability to think creatively will be nourished like a habit. In fact, this assertion is based on the assumption that creativity can be regarded as a thinking style or a thinking habit rather than a general cognitive ability (Richard, 2007). For instance, Kim (2005) reported, based on a meta-analysis of studies from 1961 to 2004, that the correlation between IQ and creativity was only 0.174. Therefore, in this study, we suggest a model of ' $\mathrm{IS}^{3} \mathrm{CA}$ : Iterative Small Scale Scientific Creative Activity', where it is recommend that these activities should be used iteratively for many school years.

- Teaching context: In this cell, among 4 kinds of teaching contexts (classroom teaching, laboratory teaching, special class teaching, or performance assessment), one context is designated.

- Type of scientific creativity activity: For this cell, the teacher can select a type of activity from the various types presented in Figure 2. The reason that we refer to the 'type' of activity is because the actual teaching materials need to be changed according to the level and interest of the students, the content of the science textbook, and the curriculum. For instance, an activity type of 'suggesting alternative and different uses of a convex lens' can be simply transformed by replacing 'convex lens' with 'spring scale' or 'bar magnet'. Here, the selection of scientific materials can be determined by the contents of the science textbook or science curriculum.

- Elements of scientific creativity: It is usually recommended that less than 3 elements among 
the nine elements of scientific creativity (Park, 2011) are involved in each activity because the activity is a small-scale one. However, different elements need to be included in different activities to help students to experience the various elements of scientific creativity through iterative experiences of scientific creativity activities.

- Activity with textbook content: The teaching materials are developed for the purpose of being used in ordinary school contexts. Therefore, the activity should be determined by and be closely related to the contents of science textbooks or the science curriculum. Therefore, in this cell, there should be a description of how the creativity activity is related to the textbook contents or to the science curriculum. For example, a small creative activity can be added into the process of carrying out an original scientific inquiry activity from the textbook, or can be inserted as a discussion activity or a game type activity after or during learning a basic concept provided in the science textbook.

- Examples of activity results: In this cell, concrete samples of activity results are provided. This cell can be extended by adding students' actual responses after applying the activity in an actual teaching class.

- Guide for creative thinking: In this part, several guides that were presented in a previous study (Park \& Jee, 2010) for helping students to think creatively are provided. Guides provided at the second stage of the $\mathrm{AGA}^{2}$ model can be utilized. Usually, less than about 3 guides are appropriate for a small scale activity.
- Tips for use and transformation of activity: To encourage more interesting or effective teaching of creativity in schools, a practical tip such as the following example can be provided: "After suggesting creative ideas in a group, let students select 2 ideas as the most creative ones in each group, and write their selected ideas on the blackboard in class. Then, teachers can ask the students to choose the most creative idea from the list on the blackboard."

\section{Teachers' responses about the in-service program and the process of developing their own teaching materials}

\section{Format of material for teaching scientific creativity}

Regarding the suggested format of teaching materials for scientific creativity (Figure, 5), elementary school teachers answered that the format was easily understandable (average response $=4.7$ for item II-1), and that the format also was useful for teaching scientific creativity in schools (average response=4.1 for item II-2), as shown in Table 4.

Operational definition of nine elements of scientific creativity

Teachers answered that the operational definitions of the nine elements of scientific creativity were understandable (average $=4.1$ for item III-1) and helpful for teaching scientific creativity in schools (average $=4.6$ for item III-2), as shown in Table 5.

When we asked whether there were unnecessary elements or omitted elements in the list of nine elements, the teachers answered as follows:

\section{Table 4}

Teachers' responses about the format of materials for teaching scientific creativity

\begin{tabular}{ccccccccc}
\hline \hline \multirow{2}{*}{$\begin{array}{c}\text { No. of } \\
\text { item }\end{array}$} & A & B & C & D & E & F & G & \multirow{2}{*}{ Average } \\
\cline { 2 - 7 } II-1 & 5 & 5 & 4 & 4 & 5 & 5 & 5 & 4.7 \\
\hline II-2 & 4 & 4 & 4 & 4 & 5 & 4 & 4 & 4.1 \\
\hline
\end{tabular}




\section{Table 5}

Teachers' responses about operational definitions of scientific creativity elements

\begin{tabular}{ccccccccc}
\hline \hline \multirow{2}{*}{$\begin{array}{c}\text { No. of } \\
\text { item }\end{array}$} & A & B & C & D & E & F & G & \multirow{2}{*}{ Average } \\
\cline { 2 - 7 } III-1 & 4 & 4 & 3 & 4 & 5 & 4 & 5 & 4.1 \\
\hline III-2 & 5 & 4 & 4 & 4 & 5 & 5 & 5 & 4.6 \\
\hline
\end{tabular}

- Originality and unusualness appear to be similar.

- Associational thinking and synthesis appear to be similar.

- Besides cognitive elements, other elements such as enjoyment or fun should be considered as elements of scientific creativity.

Therefore, we found that more detailed descriptions and instances of originality, unusualness, associational thinking, and synthesis are necessary, as follows:

- Originality means new ideas or products that others have not previously suggested or invented. To determine the originality, the suggested ideas or product should be compared with those of others. For example, if only 5 persons suggested a certain idea among 100 persons, then the idea can be called 'original.
Of course, this '5\%' standard is not absolute. Therefore, in the case of a creativity contest, a lower standard such as the '3\%' standard can be used, and in the case of ordinary classroom teaching, a '10\%' standard can be used to encourage students' activities.

- Unusual thinking corresponds to having ideas that are different from conventional or traditional ideas. To define what we mean by unusualness, we suggested more concrete instances of unusual thinking, which are as follows: (1) thinking reversely, (2) changing the basic structure of the construction, (3) changing basic assumptions or conditions involved in scientific phenomena, and (4) changing ordinary scientific definitions or laws (Figure 6).

- For associational thinking, it is important to link two ideas meaningfully. For example, the generation of an analogy or metaphor to explain

Sample activity of thinking reversely

- A speaker can convert electricity to sound. But, if we speak into the front of the speaker, then the speaker can be used as a microphone because it can convert sound to electricity.

Sample activity of modifying the ordinary structure of a simple scientific instrument

- The ordinary needle camera has only one hole. If there are two or three holes, or if the hole is changed into a slit, then we can observe different and interesting images.

Sample activity of changing basic assumptions involved in a scientific phenomena or law

- If ordinary glass is located in the air, then light can be refracted when passing through the glass. This is because the index of refraction of the glass is different from the index of refraction of the air. If you put the glass inside a certain transparent liquid having the same index of refraction as the glass, then light can go straight without refraction. Also, the glass cannot be seen, as if it is an invisible man'.

Sample activity of changing the ordinary definition of a scientific law

- The conventional definition of speed is ' $s / t$ '. If you change the definition of speed to ' $t / s$ ', then it is not correct scientifically. But you can find that this transformed definition is useful to determine who is faster in a sports game. 
1. The 'index of refraction' and 'falling speed of an object in air' appear to have no relationship between the two. However, the index of refraction is defined as the ratio of the speeds of light in the vacuum and medium. Also, the speed of a falling object is affected by the properties of the medium. Therefore, the two can be linked with each other as follows: "Two are determined by the property of the medium."

Now, suggest any relationships between the following pairs of concepts.
(1) law of reflection $\leftarrow \rightarrow$ collision
(2) Hook's law $\leftarrow \rightarrow$ Faraday law

(3) magnetic field $\leftarrow \rightarrow$ atom

(4) velocity $\leftarrow \rightarrow$ battery

2. There are many interesting proverbs in our life.

(1) Search for interesting proverbs on the internet, and find out any scientific knowledge embedded in the proverbs, as in the following example. (ex) No smoke without fire. $\rightarrow$ cause and effect in scientific law

(2) Search for interesting scientific phenomena, and suggest a proverb representing the main features of the scientific phenomena, as in the following example. (ex) Speed of light is $300,000 \mathrm{~km} / \mathrm{s} \rightarrow$ (suggested proverb) Light without legs travels fast.

\section{Fig. 7 Examples of activities for associational thinking}

or understand abstract concepts corresponds to associational thinking. In this case, recognizing the similarity between the analogy and the abstract concept is the crucial point. Suggesting a new scientific hypothesis by using abductive reasoning (Park, 2006) is also a type of associational thinking. A sample activity related to this type of associational thinking can be seen in another report (Park, 2011).

However, not only similarity-based connections correspond to associational thinking. The linkage of two ideas that are seemingly irrelevant is another type of associational thinking. Figure 7 shows some examples of this second type of associational thinking.

- In the case of synthesis, the important thing is the number of ideas or functions included in a structured system or construction. For instance, the number of concepts included in a concept map corresponds to the degree of synthesis. The number of functions involved in a new invention is also the result of synthetic thinking. For instance, if a certain laser pointer also functions as a pencil, small radio, pointing rod, lantern using a bright LED, and screwdriver, then the number of functions of the laser pointer corresponds to the degree of synthesis.
Therefore, the synthesis score is 6 if one point is given for each function.

Compared to associational thinking with synthesis, meaningful connections are important for associational thinking where the number of connections is not important, but the number of any connections is the crucial aspect of synthesis. Therefore, the level of synthesis can be raised through encouraging many instances of associational thinking.

\section{Four types of teaching contexts for scientific creativity}

In this study, I suggested four teaching contexts for scientific creativity. Elementary teachers responded that the suggested four contexts were easily understandable (average $=4.6$ for item IV-1), and also would be useful in an ordinary school context (average $=4.1$ for item IV-2). Therefore, they would be practical for teaching scientific creativity in schools (average 4.1 for item IV-3). These results are shown in Table 6.

When asked if there were additional conditions or supports required for more successful teaching of scientific creativity in schools, they answered as follows: 
Table 6

Teachers' responses about four teaching contexts for scientific creativity

\begin{tabular}{ccccccccc}
\hline \hline \multirow{2}{*}{$\begin{array}{c}\text { No. of } \\
\text { item }\end{array}$} & A & B & C & D & E & F & G & \multirow{2}{*}{ average } \\
\cline { 2 - 8 } IV-1 & 5 & 4 & 5 & 4 & 5 & 5 & 4 & 4.6 \\
\hline IV-2 & 4 & 4 & 4 & 4 & 5 & 4 & 4 & 4.1 \\
\hline IV-3 & 5 & 4 & 4 & 4 & 5 & 4 & 3 & 4.1 \\
\hline
\end{tabular}

- Teachers should be able to assess the creativity under free and unrestricted circumstances. Also, people should trust the scores given by teachers.

- Many practical teaching materials based on the school curriculum should be developed and distributed.

- For teaching scientific creativity, the quantity of subject contents needs to be decreased.

- Teaching materials need to be simpler and easier in order to nourish creative thinking. That is, the requirement of scientific knowledge needs to be decreased in the performing of creative tasks.

- Usually, people think that performing creative tasks requires a high level of ability, but we need a creativity program that is effective even for underachieving children.

- Game-type activities for arousing motivation and interest will be helpful if they are used at the beginning of an ordinary learning session in the classroom.

\section{Examples of teaching materials and their development}

The format of teaching materials for scientific creativity contains various elements such as the title, time needed for the activity, and so on. Teachers answered that the suggested elements included in the format of teaching scientific creativity were all necessary (average $=4.0$ for item V-1). However, they also answered that eight examples of teaching materials were not sufficient for developing their own teaching materials (average $=3.6$ for item $\mathrm{V}-3$ ).

Teachers also answered that the suggested eight examples needed to be shown to other teachers (average $=4.4$ for item V-4), and they said that they would develop about five of their own teaching materials for the purpose of using them in their school (for item V-5). They also responded that the suggested examples of teaching materials would be very helpful for developing their own materials (average 4.6 for item V-6). These results are shown in Table 7.

Regarding item $\mathrm{V}-2$, teachers answered that the following elements needed to be added into the format of the teaching materials:

- Appropriate stage where the creative activity

Table 7

Teachers' responses about suggested examples of teaching materials

\begin{tabular}{ccccccccc}
\hline \hline \multirow{2}{*}{$\begin{array}{c}\text { No. of } \\
\text { item }\end{array}$} & \multicolumn{7}{c}{ Teacher } & \multirow{2}{*}{ Average } \\
\cline { 2 - 7 } V -1 & 3 & 4 & 5 & 4 & 4 & 4 & 4 & 4.0 \\
\hline $\mathrm{V}-3$ & 3 & 3 & 5 & 3 & 4 & 3 & 4 & 3.6 \\
\hline $\mathrm{V}-4$ & 5 & 5 & 5 & 4 & 3 & 4 & 5 & 4.4 \\
\hline $\mathrm{V}-5$ & 5 & 5 & 5 & 5 & 5 & 5 & 5 & 5.0 \\
\hline $\mathrm{V}-6$ & 5 & 5 & 5 & 5 & 4 & 4 & 4 & 4.6 \\
\hline
\end{tabular}


is introduced in their teaching plan.

- Summary describing the basic goals and contents of the activity (for helping other teachers to understand the activity easily).

- More figures and drawings (and sometimes an interesting demonstration) are necessary (for arousing students' interest).

Finally, for item V-7, teachers recommended that the following conditions or supports were necessary for successful development of their own teaching materials:

- More various and practical guides for how to think creatively are necessary.

- Sample activities should be developed for the level of elementary students. That is, the scientific concepts involved in some of the example activities were difficult for elementary students.

\section{Characteristics of the developed teaching materials by teachers}

\section{Teaching context}

After receiving a brief (3 hours) in-service training about teaching scientific creativity, seven teachers (participants) developed a total of 35 teaching materials for the purpose of applying them in their school teaching. According to Table 8, it was found that teachers preferred ordinary classroom (37.1\%) or laboratory $(40.0 \%)$ contexts for teaching scientific creativity in their schools rather than special classes such as a 'science class', or 'class for gifted education'. From this, we realized that teachers sympathized with our basic research goal.

\section{Types of scientific creativity activity}

As mentioned earlier, the samples of scientific creativity activities shown in Figure 2 were provided and teachers were told to revise them according to their students' interest, level, or school curriculum. In addition, in the format shown in Figure 5, a tip for transforming the provided sample activity was also included.

According to Table 9, Type I activities were the most frequently used in developing teaching materials and Type III were the least used. This may be because the level of scientific knowledge teaching in elementary school is low.

\section{Elements of scientific creativity}

Table 10 shows what kinds of elements of scientific creativity were included in the teaching materials developed by teachers. In Table 10, we can see that divergent thinking was the most involved element of creative thinking, whereas associational thinking was the least. More concretely, originality was the most frequently used in developing the materials, whereas

\section{Table 8}

Distribution of four teaching contexts in teaching materials developed by teachers

\begin{tabular}{ccccc}
\hline \hline Teaching context & Classroom & Laboratory & Special class & $\begin{array}{c}\text { Performance } \\
\text { assessment }\end{array}$ \\
\hline $\begin{array}{c}\text { Number of } \\
\text { activities }\end{array}$ & $13(37.1 \%)$ & $14(40.0 \%)$ & $3(8.6 \%)$ & $5(14.3 \%)$ \\
\hline
\end{tabular}

\section{Table 9}

Creativity activity types used by teachers

\begin{tabular}{|c|c|c|c|c|c|c|c|c|c|c|c|c|c|c|c|c|}
\hline Type & $\mathrm{I}-1$ & $\mathrm{I}-2$ & $\mathrm{I}-3$ & $\mathrm{I}-6$ & $\mathrm{I}-8$ & I-9 & $\mathrm{I}-12$ & $\mathrm{I}-13$ & II-1 & II-2 & II-6 & $\mathrm{II}-7$ & $*$ & III-1 & $\mathrm{III}-4$ & III-11 \\
\hline \multirow{2}{*}{ No. } & 8 & 2 & 1 & 2 & 1 & 4 & 1 & 1 & 1 & 1 & 1 & 2 & 4 & 1 & 4 & 1 \\
\hline & \multicolumn{8}{|c|}{$20(57.1 \%)$} & \multicolumn{5}{|c|}{$9(25.7 \%)$} & \multicolumn{3}{|c|}{$6(17.1 \%)$} \\
\hline
\end{tabular}

\footnotetext{
*scientific inquiry activity including whole inquiry skills
} 
simplicity was the least. Examples of activities for teaching simplicity in science can be finding regularities from complex data', 'suggesting new symbols or mathematical formula to represent new ideas', or 'drawing a table, graph, or diagram to simplify complex data'. Therefore, these kinds of activities are not easily applied for elementary school students.

According to Table 10, a total of 169 elements were included in a total of 35 activities; therefore, the average number of creativity elements per one activity was 4.8. Four or five elements are appropriate for ordinary creativity activities designed for improving the students' creative ability if sufficient time is allowed. However, the basic goal of this study was to encourage students into the habit of thinking creatively under ordinary learning situations in school by repeating small activities iteratively. Therefore, we need to recommend a lower number of creativity elements, for example $2 \sim 3$, in each activity.

\section{Other characteristics found in teaching materials developed by teachers}

We introduced several types of activities as shown in Figure 2 to the teachers. However, this list of the types of scientific creativity activities cannot be complete. In fact, some teachers said that it was not easy to determine which type of activity was appropriate to the content of the science textbook that they use to teach a certain science concept. Therefore, we need to develop more various types of creativity activities. Regarding this, I started another study to investigate various creativity activities to find new types of creativity activities. For example, besides the three main types in Figure 2, we are also developing other types, such as, creative solving of scientific problems' and 'SCAMPER activities in scientific contexts'. In due course, I hope to report the results of this study.

Secondly, some teachers showed special concerns about the items 'examples of activity results' and 'guide for creative thinking' in the format. That is, they wanted a greater variety of examples of activity results and guides for creative thinking (This aspect was also found from teachers' responses about question items V-7 as mentioned earlier). This need can be resolved by having the teachers conduct activities by themselves rather than just providing them with pre-determined solutions. This means that carrying out the creativity activity can help teachers to realize what kinds of results of the activity are possible and what kinds of thinking can lead to such results. This is similar to the case in which teachers conduct authentic scientific research by themselves to realize the nature of scientific inquiry. For example, Silverstein et al. (2009) reported that teachers who experienced actual scientific research could enhance the quality and authenticity of their science teaching; as a result, they could contribute to the improvement of students' achievement in science. Therefore, actual experience of conducting creative activities can help teachers to teach scientific creativity to students in a more effective and authentic way.

\section{Suggestion of curriculum for teaching scientific creativity}

To date, I have developed some samples of teaching materials for scientific creativity to be

Table 10

Number of elements of scientific creativity in teaching materials developed by teachers

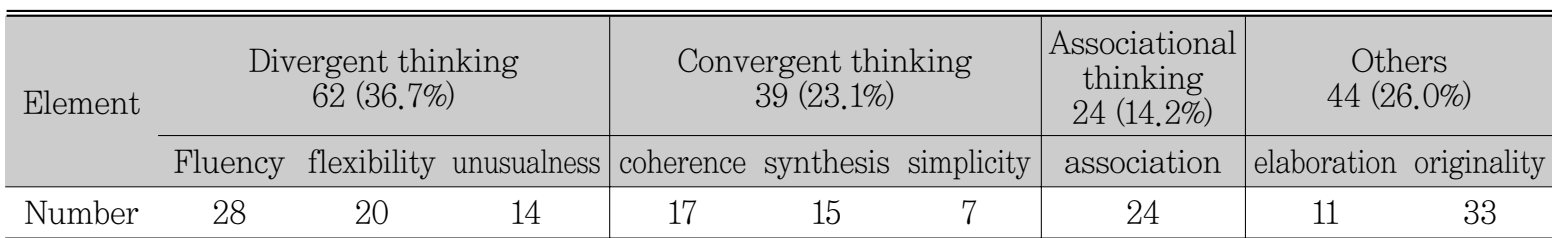


used in an ordinary school context and applied them to a small number of elementary school teachers. To widen the scope and generalize this study, here I suggest a scientific creativity curriculum as shown in Figure 8.

In this curriculum, the levels of activity are divided based on what the activity focuses on. In the 'practice' level, students experience how to think creatively with concrete examples, then they are asked to imitate and practice with the examples. The basic goal of this activity is to make creative activities fun and familiar to students.

In the 'process' level, students are given guidance about how to think creatively more concretely, then students suggest their own ideas using the guides. The basic goal of this activity is to help students to recognize how various and effective thinking strategies can be used to generate creative ideas. To do this, the teacher needs to provide various and effective guides at first, to stimulate students to suggest their own ideas using the guides, and moreover, to encourage them to find their own methods for suggesting creative ideas.

In the 'product' level, students are asked to create concrete products as a result of creative thinking processes. To do this, students need to select, refine, articulate the suggested initial ideas, and to create various forms of a product, such as a blueprint, a manufactured product, an idea proposal, figures or models representing ideas, a report representing the process and the result, and so on.

Because the basic concern of this study is scientific creativity, scientific knowledge or scientific inquiry skills should be included, used, or applied when conducting the creative task. However, using and applying scientific knowledge or inquiry skills are difficult to students in lower grades. Therefore, for grade 3 or 4 students, only the scientific context is provided in the task. To do this, scientific phenomena (e.g. a rainbow) or scientific materials (e.g. a thermometer) can be used to give a scientific context to the task. For example, by comparing the following two tasks, we can say that the second task corresponds to a scientific creative activity because it uses scientific materials (a spring scale).

- Suggest alternative uses of a glass cup, other than putting water or other materials into the cup.

- Suggest alternative uses of a spring scale, other than measuring the weight of materials.

Finally, the number of elements of scientific creativity can differ according to the grade of the students. However, even for higher grade students, only about three elements are recommended because this activity will be used as a form of small-scale activity which requires just 10 or 15 minutes.

The operational definitions of each element of scientific creativity (Fluency, Flexibility, Unusualness, Synthesis, Coherency, Simplicity, Similarity-based reasoning, Linking without similarity, Originality, Elaboration, Value, and so on) are provided in the second cell of the curriculum. In Figure 8, the operational definition of fluency is described, but other definitions can be seen in other articles (Park, 2011).

Various types of tasks for scientific creativity can be listed in the next cell. To do this, Figure 2 can be used. Of course, besides these types, other types of scientific creativity can also be included.

In the next cell, standards for the evaluation for each element of scientific creativity are provided. Information about evaluation standards for the remaining elements can be seen in Park's (2011) article.

Finally, samples of activities corresponding to each grade level are described in the last cell of the curriculum. In the sample activity, the following information is given in the parentheses; the element of scientific creativity, 


\begin{tabular}{|c|c|c|c|}
\hline Grade & $3 \sim 4$ & $5 \sim 6$ & $7 \sim 12$ \\
\hline \multirow{2}{*}{$\begin{array}{c}\text { Focus of } \\
\text { Activity }\end{array}$} & $\begin{array}{c}\text { Practice } \\
\text { Students imitate and practice } \\
\text { the provided examples of } \\
\text { scientific creative activities. }\end{array}$ & $\begin{array}{c}\text { Process } \\
\text { process of generating } \\
\text { creative ideas. }\end{array}$ & $\begin{array}{c}\text { Students generate various } \\
\text { forms of products as a result } \\
\text { of scientific creative process. }\end{array}$ \\
\cline { 2 - 4 } $\begin{array}{c}\text { Scientific } \\
\text { Knowledge \& } \\
\text { Inquiry Skills }\end{array}$ & $\begin{array}{c}\text { Simple activity is provided in } \\
\text { scientific context. }\end{array}$ & $\begin{array}{c}\text { Activity uses or contains basic } \\
\text { level of scientific knowledge or } \\
\text { inquiry skills }\end{array}$ & $\begin{array}{c}\text { Activity requires application } \\
\text { of scientific knowledge and } \\
\text { inquiry skills }\end{array}$ \\
\hline \multirow{2}{*}{$\begin{array}{c}\text { Elements of } \\
\text { Scientific } \\
\text { Creativity }\end{array}$} & $\begin{array}{c}\text { Only 1 2 elements of scientific } \\
\text { creativity are simply required } \\
\text { to use to conduct the activity }\end{array}$ & $\begin{array}{c}\text { About 2 3 elements of } \\
\text { scientific creativity are } \\
\text { contained in each activity. }\end{array}$ & $\begin{array}{c}\text { About 3 elements of scientific } \\
\text { creativity are required to } \\
\text { conduct creative task }\end{array}$ \\
\hline
\end{tabular}

[Operational definition of the elements of scientific creativity]

- Fluency: This means the number of ideas or products. All ideas or products can be counted to evaluate the fluency in ordinary creativity, but, in the case of scientific creativity, we select only those ideas or products which use or include scientific knowledge, which can be used in the process of scientific inquiry, or which have scientifically valid rationale.

- Flexibility: $\cdots$

[Types of scientific creative task]

- Inventing various alternative scientific usages

- Making predictions scientifically in unusual situations

...

[Evaluation of scientific creativity]

- Fluency: Give 1 point for each idea or product. However, if the idea or product uses or applies scientific knowledge or can be used at the process of scientific inquiry, 2 points can be given for that idea or product.

- Flexibility: $\cdots$

...

[Example of scientific creative task]

- Task for the grade 3 4 students: Ordinary magnifying glass (activity in a scientific context) can be used alternatively. For example, if you melt the glass, then it can be used to make a glass rod. Now, suggest your ideas by melting the glass. When suggesting ideas, it is important to suggest as many ideas as possible (one element of scientific creativity, fluency, is included).

- Task for the grade 5 6 students: Make a story including 'magnet' and a 'humidity'. When making a story, try to suggest new ideas which others do not think of (this corresponds to originality), and check whether the suggested ideas are scientifically plausible or not (this corresponds to coherence).

To do this, utilize the following guides about how to think creatively, and cooperate with others to think creatively (2 3 guidelines should be provided). You are encouraged to find your own thinking methods to suggest creative ideas.

- Task for the grade 7-10 students: Draw your own 'Rube Goldberg machine'. When drawing it, it is important to include as many steps as possible (this corresponds to synthesis), and also to include various energy conversions (application of scientific knowledge). And describe how energy is converted in each step (this corresponds to coherence). You should draw the machine in detail (this corresponds to elaboration). Your machine drawing (product) will be exhibited for a few days and will be evaluated by peers. (To help students with the drawing, guides can be provided.) 
the practice/process/product, and the necessary guides and examples.

\section{Summary and Conclusion}

The basic goal of this study is to suggest a more practical way of teaching scientific creativity in an ordinary school context rather than in a special educational system such as the gifted education system. To achieve this, the following processes were performed in this study.

At first, we determined four types of teaching contexts: teaching in an ordinary classroom, teaching in a school laboratory, teaching in a special class such as a science class, and performance assessment.

Secondly, we developed a format of teaching materials for teaching scientific creativity, and developed eight samples of teaching materials using the format. The reason that the format was suggested is because the format can be used as a basis for ordinary school teachers who want to develop their own teaching materials. That is, the format can lead to the generalization of the development process of teaching materials by school teachers.

To apply the developed format and teaching materials in ordinary school situations, I suggested the model of IS $^{3} \mathrm{CA}$ (Iterative Small Scale Scientific Creative Activity). This model is suggested based on an assumption that scientific creativity can be improved as a form of thinking habit or thinking style rather than as a cognitive ability; therefore, it is recommended that this model should be used iteratively for many years from elementary school to secondary high school.

Thirdly, we developed a brief in-service program of three hours' duration for elementary school teachers to introduce basic information about scientific creativity. Afterwards, teachers gave us responses about the in-service program. From the teachers' various positive responses, we were assured that the in-service program was helpful for teachers.

Fourth, teachers developed 35 teaching materials by themselves for teaching scientific creativity in their schools. We analyzed the characteristics of the teachers' teaching materials and obtained information about the process of developing materials. From this analysis and information, we could confirm that even this brief in-service program using the format and teaching materials could help ordinary school teachers to develop their own teaching materials for scientific creativity for the purpose of using them in their ordinary schools. This means that the teaching of creativity by ordinary school teachers in ordinary school situations is possible. However, we suggested the following recommendations for more effective ways of teaching scientific creativity in the ordinary school context.

- A smaller number (for instance 2 or 3 ) of elements of creativity need to be involved in each creativity activity. Instead, many small activities (which can be conducted for 10 20 minutes) should be taught iteratively (through low grades to high grades for many years).

- More varied types of creativity activity need to be developed and introduced for teachers' practical use.

- Teachers need to conduct creativity activities by themselves. This experience can help them to realize the nature and characteristics of scientific creativity and, as a result, help them teach students how to think creatively.

Finally, based on the above experiences, we suggested a curriculum of scientific creativity for the purpose of its application to the national science curriculum. The curriculum for scientific creativity indicates what levels of activity can be used from lower grades to higher grades according to the following three aspects:

- Activities were focused mainly on the following: (1) practices imitating or using the provided examples in the lower grades, (2) processes about how to think creatively in the 
medium grades, and (3) products as a result of scientific creative processes in the higher grades.

- Scientific knowledge or scientific inquiry skills are (1) not required distinctly but the creative task is conducted according to the appropriate scientific context for low grade students, (2) included in the process of performing the task for medium grade students, and (3) applied to conduct the task in the case of higher grade students.

- The number of elements of scientific creativity are (1) one or two for students in a low grade, (2) two or three in a medium grade, and (3) about three in a higher grade.

This study is practical rather than theoretical. Also, this study stands at a starting point rather than reporting the final result. That is, recommendations obtained from teachers' responses and experiences of developing teaching materials for scientific creativity should be realized in developing more types of actual teaching materials, guides for teaching scientific creativity, and designing a science curriculum.

Regarding these considerations, as mentioned earlier, another study to develop more types of activities for teaching scientific creativity titled, 'Analysis of Types of Activities for Scientific Creativity' was started. The suggested scientific creativity curriculum in this study has already been applied to another research project titled, 'A Study for Developing the Standard of Science Content. Finally, I with my doctoral students have started to develop a new approach for learning scientific creativity at home. The basic goal of this study is also to make teaching and learning scientific creativity easier. We have already obtained very positive results from that study, therefore, I am sure that improving scientific creativity is possible in ordinary and even informal situations.

\section{References}

AAAS (American Association for the
Advancement of Science) (1990). Science for All Americans: Project 2061. NY: Oxford University Press.

Baer, J. (1999). Domains of creativity. In M. A. Runco \& S.R. Pritzker (Eds.) Encyclopedia of Creativity (pp. 591-596). London: Academic Press,

Conti, R., Coon, H., \& Amabile, T. M. (1996). Evidence to support the componential model of creativity: Secondary analyses of three studies. Creativity Research Journal, 9, 358-389.

Corte, E.D. (2000). Marrying theory building and the improvement of school practice: a permanent challenge for instructional psychology, Learning and Instruction, 10, 249266.

Cropley, A.J. (1992). More Ways Than One: Fostering Creativity, Connecticut: Greenwood Publishing Group.

Hu, W., \& Adey, P. (2002). A scientific creativity test for secondary school students. International Journal of Science Education, 24(4), 389-403.

Kim, K. H. (2005). Can only intelligent people be creative? The Journal of Secondary Gifted Education, 16(2/3), 57-66.

Mansfield, R. D., \& Busse, T. V. (1981). The Psychology of Creativity and Discovery: Scientists and Their Work. Chicago: NelsonHall.

MEST (Ministry of Education, Science and Technology) (2009). 2009 Revised Curriculum: General Introduction of Elementary, Junior and Senior High School Curriculum. Seoul: MEST.

National Curriculum Board (2009). Shape of Australian Curriculum: Science. Retrieved at

Park, Jongwon (2004). A suggestion of cognitive model of scientific creativity, Journal of the Korean Association for Science Education, 24(2), 375-386.

Park, Jongwon (2006). Modelling analysis of student's processes of generating scientific explanatory hypothesis. International Journal of Science Education, 28(5), 469-489.

Park, Jongwon, Park Jongseok, and Lee, 
Ganggil (2008). Development of Scientific Creativity Activities (KRF-2007-721-B00034, 2008).

Park, Jongwon, et al. (2009). Development and Distribution of Mathematics and Integrated Science Teaching Materials for Science Gifted Education Center (Report of KOFAC, 2009).

Park, Jongwon, et al. (2010). Development and Distribution of On-line Activities for Scientific Creativity (Report of KOFAC, 2010).

Park, Jongwon., \& Jee, Kjoungjun (2010). Characteristics of scientifically gifted students' performance processes in the creative tasks. Journal of the Korean Association for Science Education, 30(6), 770-784.

Park, Jongwon (2011). Understanding and teaching scientific creativity in schools. New Physics: Sae Mulli, 61(10), 947-961.

Park, Jongwon (unpublished). Analysis of Types of Activities for Scientific Creativity.

Plucker, J. A. (2004). Generalization of creativity across domains: Examination of the method effect hypothesis. Journal of Creative Behavior, 38, 1.12.

Richards, R. (2007). Everyday creativity: Our hidden potential. In R. Richards (Ed.), Everyday creativity and new views of human nature (pp. 25 54). Washington, DC: American Psychological Association.

Rose, L. H., \& Lin, H. T. (1984). The metaanalysis of long-term creativity training programs. Journal of Creative Behavior, 18, 1122.

Scott, G., Leritz, L. E., \& Mumford, M. D. (2004a). The effectiveness of creativity training: A quantitative review. Creativity Research Journal, 16, 361-388.

Scott, G., Leritz, L. E., \& Mumford, M. D. (2004b). Types of creative training: Approaches and their effectiveness. Journal of Creative Behavior, 38(3), 149-179.

Siverstein, S. C., Dubner, J., Miller, J., Glied, S., and Loike, J. D. (2009). Teachers' participation in research programs improves their students' achievement in science, Science, 326, 440-442.

Treffinger, D. J., Sortore, M. R., \& Cross, J. A. (1993). Programs and strategies for nurturing creativity. In K. A. Heller, F. J. Monks \& A. H. Passow (Eds.), International handbook for research on giftedness and talent (pp. 555-567). Oxford: Pergamon.

Yager, R. E. (1989). Development of student creative skills: A guest for successful science education. Creativity Research Journal, 2(3), 196-203

Weisberg, R. W. (2006). Creativity: Understanding Innovation in Problem Solving, Science, Invention, and the Arts. NJ: John Wiely \& Sons.

Wolpert, L. (1992). The Unnatural Nature of Science. Cambridge: Harvard University Press. 


\section{[Appendix] Example of teaching materials}

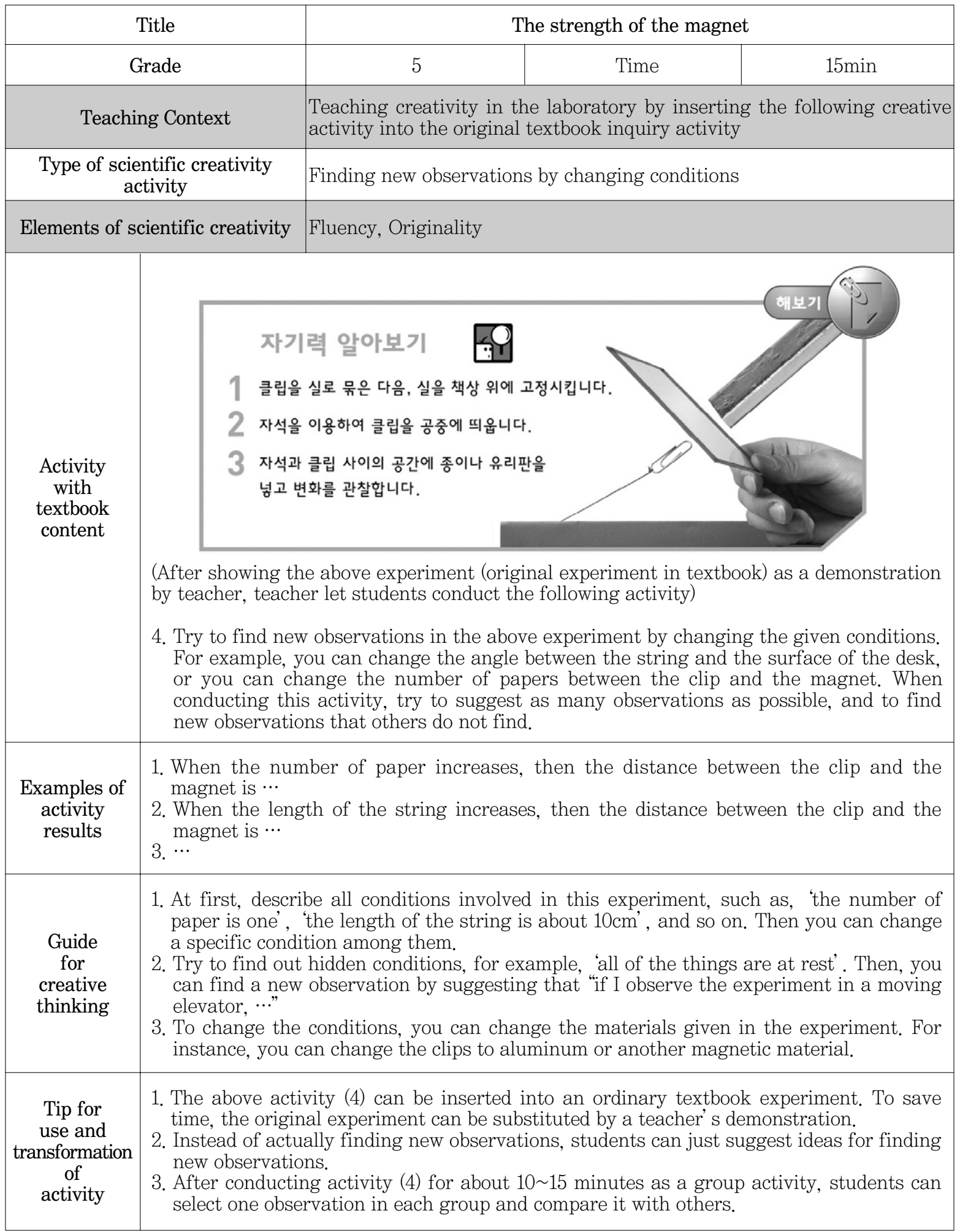

